\title{
PENGARUH LAYANAN INFORMASI TENTANG STUDI LANJUT TERHADAP PERENCANAAN KARIR SISWA KELAS XI IPA SMA NEGERI 1 PEKANBARU TAHUN AJARAN 2013/2014
}

\author{
Ledya Oktavia Liza' ${ }^{1}$, M. Arli Rusandi²)

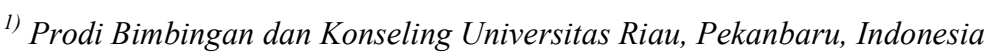 \\ E-mail:Ldyoktavializa@gmail.com \\ 2) Prodi Bimbingan dan Konseling Universitas Lambung Mangkurat, Banjarmasin, Indonesia \\ E-mail: arlirusandi@gmail.com
}

\begin{abstract}
Abstrak. Penelitian ini bertujuan untuk ; 1) Untuk mengetahui gambaran perencanaan karir siswa sebelum diberikan layanan informasi tentang studi lanjut. 2) Untuk mengetahui gambaran perencanaan karir siswa sesudah diberikan layanan informasi tentang studi lanjut. 3) Untuk mengetahui perbedaan perencanaan karir siswa sebelum dan sesudah diberikan layanan informasi tentang studi lanjut. 4) Untuk mengetahui pengaruh layanan informasi tentang studi lanjut terhadap perencanaan karir siswa. Metode yang digunakan adalah metode Quasi experiment, dengan menggunakan One group pretest-postest design. Populasi penelitian ini adalah siswa kelas XI IPA SMA Negeri 1 Pekanbaru dan sampelnya adalah $50 \%$ dari populasi, dengan menggunakan teknik simple random sampling. Berdasarkan hasil pengolahan data maka perencanaan karir siswa sebelum diberikan layanan informasi tentang studi lanjut sebagian besar berada pada kategori sedang, sedangkan sesudah diberikan layanan informasi tentang studi lanjut perencanaan karir siswa sebagian besar berada pada kategori sangat baik dan baik. Dari perhitungan uji-t diperoleh $t_{\text {hitung }}$ lebih besar dari $t_{\text {tabel }}(20,9>1,960)$ maka hipotesis diterima, terdapat perbedaan yang signifikan antara perencanaan karir siswa kelas XI IPA SMA Negeri 1 Pekanbaru sebelum dan sesudah dilakukan layanan informasi tentang studi lanjut pada taraf kesalahan 5\%. Berdasarkan hasil perhitungan koefisian korelasi dan koefisien determinan, maka kontribusi layanan informasi tentang studi lanjut terhadap perencanaan karir adalah sebesar 38\% sedangkan 62\% lainnya dipengaruhi oleh variabel lain.
\end{abstract}

Kata kunci: Layanan Informasi; Perencanaan Karir

\section{PENDAHULUAN}

Salah satu tugas perkembangan remaja adalah mempersiapkan kelanjutan studi atau karir [1]. Remaja disini adalah siswa SMA yang harus mempunyai rencana terhadap karirnya. Hal ini sangatlah penting bagi siswa untuk memudahkannya dalam menentukan arah studi yang akan diambil. Apabila siswa tidak dengan baik merencanakan karirnya, maka akan berdampak tidak baik bagi pilihannya terhadap studi lanjut.

Perencanaan karir adalah sebagai proses yang dilalui sebelum pemilihan karir (Parsons [2]). Sering kali terjadi kesalahan dalam mengambil pilihan karena adanya beberapa faktor, baik faktor internal maupun faktor eksternal. Salah satunya adalah kurang nya informasi tentang studi lanjut. Hal ini sering terjadi pada siswa SMA yang akan menentukan rencana karirnya untuk masa depan yang lebih baik.

Peraturan pemerintah [3] mengemukakan bahwa standar kompetensi lulusan pada satuan pendidikan menengah umum bertujuan untuk meningkatkan kecerdasan, pengetahuan, akhlak mulia, serta ketrampilan untuk mandiri dan mengikitu pendidikan lebih lanjut. Hal ini menunjukkan bahwa siswa SMA harus mempersiapkan diri untuk karirnya kedepan yang sesuai dengan bakat dan minatnya. Karena masih banyak siswa yang tidak sesuai dalam menentukan studi lanjut sehingga berdampak tidak baik pada perencanaan karirnya. Sering terjadi kesalahan dalam perencanaan karir karena kurang mendapat informasi tentang studi lanjut. Salah satu contohnya banyak nya siswa yang ikut-ikutan dalam menentukan studi lanjut.

Kondisi seperti ini juga dialami oleh sebagian besar siswa kelas XI IPA SMA Negeri 1 Pekanbaru. Banyak siswa yang masih bingung tentang studi lanjut dan tidak mengerti arah dari sekolah lanjutan yang berhubungan dengan perencanaan karirnya. Berdasarkan wawancara dan proses konseling dengan siswa, banyak siswa yang belum memahami kemampuan dirinya sendiri, kurangnya informasi dan mendapatkan informasi yang berbeda-beda, sehingga membuat siswa tersebut menjadi bingung. Hal ini sangatlah tidak baik terjadi pada siswa, karena akan berpengaruh pada masa depannya. Terkait dengan fenomena tersebut, penulis ingin mengetahui kebutuhan siswa tentang perencanaan karir melalui Identifikasi Kebutuhan Masalah Siswa (IKMS). Berdasarkan data yang diambil melalui Identifikasi Kebutuhan 
Masalah Siswa (IKMS) pada siswa SMA Negeri 1 Pekanbaru, maka didapatlah hasil sebagai berikut :

1. Orientasi tentang sistem belajar di perguruan tinggi $(78,1 \%)$

2. Orientasi tentang syarat memasuki studi lanjut $(71,9 \%)$

3. Informasi tentang sikap yang harus dilakukan saat berbeda pendapat dengan orang tua $(65,6 \%)$

4. Informasi tentang strategi memasuki pendidikan studi lanjut $(56,3 \%)$

5. Cemas kalau menjadi penganggur setelah menyelesaikan pendidikan $(43,8 \%)$

6. Kiat menghadapi semakin ketatnya persaingan dalam masuk pendidikan lanjutan $(21,9 \%)$

Berdasarkan data tersebut, maka bisa dilihat bahwa siswa yang masih belum yakin dengan perencanaan karirnya kedepan dan kurang nya informasi tentang studi lanjutan. Jika tidak ada upaya untuk memperbaiki hal tersebut, jelas akan berdampak buruk pada masa depan siswa dan juga bisa berdampak pada sumber daya manusia. Untuk itu salah satu langkah yang harus diambil adalah siswa perlu mendapatkan informasi tentang studi lanjut dengan baik untuk perencanaan karir yang baik juga. Hal tersebut bisa dilakukan dengan salah satu bentuk layanan yaitu layanan informasi tentang studi lanjut.

Layanan informasi adalah layanan bimbingan konseling yang memungkinkan peserta didik (klien) menerima dan memahami berbagai informasi (seperti informasi pendidikan dan informasi jabatan) yang dapat digunakan sebagai bahan pertimbangan dan pengambilan keputusan untuk kepentingan peserta didik (klien) [4]. Dalam hal ini adalah informasi yang akan diberikan adalah informasi tentang studi lanjut. karir adalah :

Penelitian yang telah dilakukan tentang perencanaan

1. Peningkatan perencanaan karir melalui layanan bimbingan kelompok pada siswa kelas X-BB SMK Islam Sudirman 1 Ambarawa. Hasil penelitiannya menunjukkan bahwa ada layanan bimbingan kelompok dapat meningkatkan perencanaan karir siswa kelas X-BB SMK Islam Sudirman 1 Ambarawa [5].

2. Hubungan antara pemanfaatan layanan bimbingan karir dengan perencanaan karir pada siswa kelas XII SMUN 4 Medan. Hasil dari penelitiannya adalah menunjukkan adanya hubungan positif antara pemanfaatan layanan bimbingan karir dengan perencanaan karir dengan sumbangan efektif layanan bimbingan karir dalam perencanaan karir sebesar $15 \%$ [6].

3. Hubungan antara regulasi diri dan perencanaan karir pada remaja putri bali. Hasil penelitiannya adalah terbukti ada hubungan yang positif antara regulasi diri dan perencanaan karir pada remaja putri bali [7].

Berdasarkan beberapa penelitian diatas belum ada penelitian tentang pengaruh layanan informasi tentang studi lanjut terhadap perencanaan karir siswa kelas XI IPA SMA Negeri 1 Pekanbaru tahun ajaran 2013/2014.

\section{METODE}

Metode yang digunakan adalah metode Quasi experiment, dengan menggunakan One group pretest-postest design. Populasi penelitian ini adalah siswa kelas XI IPA SMA Negeri 1 Pekanbaru dan sampelnya adalah 50\% dari populasi, dengan menggunakan teknik simple random sampling.

III. HASIL DAN PEMBAHASAN

Tabel 1

Tolok Ukur Perencanaan Karir Siswa

\begin{tabular}{cc}
\hline Kategori & Tolok Ukur \\
\hline Sangat Baik & $140-165$ \\
Baik & $114-139$ \\
Sedang & $88-113$ \\
Kurang Baik & $62-87$ \\
Tidak Baik & $33-61$
\end{tabular}

Sumber : data olahan penelitian 2014

Berdasarkan tabel diatas maka penulis menentukan kategori perencanaan karir siswa bahwa pada tolok ukur 140-165 dikategorikan sangat baik, 114-139 dikategorikan baik, 88-113 dikategorikan sedang, 62-87 dikategorikan kurang baik dan 33-61 tidak baik.

Tabel 2

Gambaran Perencanaan Karir Siwa Sebelum diberikan Layanan Informasi tentang Studi Lanjut

\begin{tabular}{|c|c|c|c|}
\hline Kategori & Tolok Ukur & $\mathbf{F}$ & $\%$ \\
\hline Sangat Baik & $140-165$ & 0 & 0 \\
\hline Baik & 114-139 & 9 & 8,11 \\
\hline Sedang & $88-113$ & 90 & 81,08 \\
\hline $\begin{array}{c}\text { Kurang } \\
\text { Baik }\end{array}$ & $62-87$ & 12 & 10,81 \\
\hline Tidak Baik & $33-61$ & 0 & 0 \\
\hline \multicolumn{2}{|c|}{ Jumlah } & 111 & 100 \\
\hline
\end{tabular}

Sumber : data olahan penelitian 2014

Berdasarkan tabel diatas maka dapat disimpulkan bahwa perencanaan karir siswa sebelum diberikan layanan informasi sebagian besar berada pada kategori sedang yaitu $81,08 \%$, kemudian $10,81 \%$ pada kurang baik dan $8,11 \%$ berada pada kategori baik. Sedangkan pada kategori sangat baik dan tidak baik tidak ada 
Tabel 3

Gambaran Perencanaan Karir Siswa Sesudah diberikan Layanan Informasi tentang Studi Lanjut

\begin{tabular}{|c|c|c|c|}
\hline Kategori & $\begin{array}{l}\text { Tolok } \\
\text { Ukur } \\
\end{array}$ & $\mathbf{F}$ & $\%$ \\
\hline Sangat Baik & $140-165$ & 39 & 35,14 \\
\hline Baik & 114-139 & 59 & 53,15 \\
\hline Sedang & $88-113$ & 13 & 11,71 \\
\hline $\begin{array}{c}\text { Kurang } \\
\text { Baik }\end{array}$ & $62-87$ & 0 & 0 \\
\hline Tidak Baik & $33-61$ & 0 & 0 \\
\hline \multicolumn{2}{|c|}{ Jumlah } & 111 & 100 \\
\hline
\end{tabular}

Sumber : olahan data penelitan 2014

Berdasarkan tabel diatas maka dapat disimpulkan bahwa perencanaan karir siswa sesudah diberikan layanan informasi adalah 53,15 berada pada kategori baik, 35,14\% pada kategori sangat baik dan $11,71 \%$ pada kategori sedang. Tidak terdapat siswa pada kategori kurang baik dan tidak baik

Tabel 4

Rekapitulasi Perencanaan Karir Siswa Sebelum dan Sesudah diberikan Layanan Informasi tentang Studi Lanjut

\begin{tabular}{cccccc}
\hline \multirow{2}{*}{ Kategori } & Tolok & \multicolumn{2}{c}{ Sebelum } & \multicolumn{2}{c}{ Sesudah } \\
& Ukur & F & \% & F & \% \\
\hline Sangat & $140-165$ & 0 & 0 & 39 & 35,14 \\
Baik & $114-139$ & 9 & 8,11 & 59 & 53,15 \\
Baik & $88-113$ & 90 & 81,08 & 13 & 11,71 \\
$\begin{array}{c}\text { Sedang } \\
\text { Kurang } \\
\text { Baik } \\
\text { Tidak }\end{array}$ & $62-87$ & 12 & 10,81 & 0 & 0 \\
Baik & $33-61$ & 0 & 0 & 0 & 0 \\
\hline \multicolumn{2}{c}{ Jumlah } & 111 & 100 & 111 & 100
\end{tabular}

Berdasarkan tabel diatas dapat disimpulkan bahwa perencanaan karir siswa sebelum diberikan layanan informasi sebagian besar berada pada kategori sedang $(81,08 \%)$ sedangkan sisanya berada pada kategori kurang baik $(10,81)$ dan kategori baik $(8,11)$, tidak ada siswa yang berada pada kategori sangat baik. Setelah dilaksanakan layanan informasi tentang studi lanjut sebagian besar siswa berada pada kategori baik $(53,15 \%)$ dan kategori sangat baik $(35,14 \%)$, sedangkan sisa nya berada pada kategori sedang $(11,71 \%)$.

Berdasarkan besar $\mathrm{dk}=220$ dengan taraf kesalahan $5 \%=1,960$, maka dapat disimpulkan bahwa $t_{\text {hitung }}$ lebih besar dari $t_{\text {tabel }}(20,9>1,960)$ pada taraf kesalahan $5 \%$ sehingga dapat disimpulkan bahwa hipotesis diterima yaitu terdapat perbedaan yang signifikan antara perencanaan karir siswa kelas XI IPA SMA Negeri 1 Pekanbaru sebelum dan sesudah dilakukan layanan informasi tentang studi lanjut.
Berdasarkan hasil olahan data penelitian maka koefisien korelasi adalah 0,62. Dari hasil koefesien korelasi tersebut maka baru bisa diketahui koefisien determinan sebagai berikut.

$$
\begin{aligned}
& \left(\boldsymbol{r}^{2}\right)=0,62^{2} \\
= & 0,38
\end{aligned}
$$

Jadi, perencanaan karir siswa kelas XI IPA SMA Negeri 1 Pekanbaru hanya 38\% dipengaruhi oleh layanan informasi tentang studi lanjut, sedangkan $62 \%$ lainnya dipengaruhi oleh variabel ataupun faktor lain.

\section{SIMPULAN DAN SARAN}

SIMPULAN

Berdasarkan penelitian dan hasil pengolahan data yang telah dilakukan peneliti, maka dapat ditarik kesimpulan sebagai berikut.

1. Sebelum diberikan layanan informasi tentang studi lanjut, perencanaan karir siswa kelas XI IPA SMA Negeri 1 Pekanbaru sebagian besar belum matang (kategori sedang) dan hanya sebagian kecil yang berada pada kategori baik dan tidak baik.

2. Sesudah diberikan layanan informasi tentang studi lanjut, perencanaan karir siswa kelas XI IPA SMA Negeri 1 Pekanbaru sebagian besar pada kategori sangat baik dan baik, sedangkan pada kategori sedang hanya terdapat sebagian kecil saja.

3. Berdasarkan hasil pengolahan data dan analisis dengan menggunakan uji-t bahwa $t_{\text {hitung }}$ lebih besar dari $t_{\text {tabel }}(20,9>1,960)$ maka hipotesis diterima, terdapat perbedaan yang signifikan antara perencanaan karir siswa kelas XI IPA SMA Negeri 1 Pekanbaru sebelum dan sesudah dilakukan layanan informasi tentang studi lanjut pada taraf kesalahan $5 \%$.

4. Layanan informasi tentang studi lanjut memberikan kontribusi terhadap perencanaan karir siswa kelas XI IPA SMA Negeri 1 Pekanbaru sebesar 38\%, sedangkan $62 \%$ lainnya dipengaruhi oleh variabel ataupun faktor lain.

\section{SARAN}

Berdasarkan hasil dari analisis data penelitian, pembahasan, temuan peneliti dan kesimpulan penelitian ini, maka peneliti memberikan saran sebagai berikut.

1. Sebelum dilakukan penelitian ini dapat dilihat bahwa siswa belum memahami dalam merencanakan karir. Untuk itu kepada pihak sekolah SMA Negeri 1 Pekanbaru untuk dapat membantu dan memperhatikan siswa dalam merencanakan karir.

2. Sesudah diadakan layanan informasi tentang studi lanjut ternyata banyak siswa yg sudah paham dalam merencanakan karir. Untuk itu kepada guru BK SMA Negeri 1 Pekanbaru agar dapat memberikan layanan 
tersebut ke seluruh siswa SMA Negeri 1 Pekanbaru dan mengembangkan materi ini dalam kegiatan MGMP.

3. Selanjutnya temuan penelitian ini menyatakan bahwa terdapat pengaruh layanan informasi tentang studi lanjut terhadap perencanaan karir siswa. Kepada para siswa SMA Negeri 1 Pekanbaru agar dapat mengikuti dan menerima dengan baik dalam proses pemberian layanan tersebut.

4. Kepada peneliti selanjutnya agar dapat meneliti layanan lainnya untuk melihat pengaruhnya terhadap perencanaan karir siswa, seperti bimbingan kelompok dankonseling kelompok.

\section{DAFTAR PUSTAKA}

1] Zulfan Saam. 2009. Psikologi Keperawatan. UR Press. Pekanbaru.

[2] Winkel, W. S, dan Sri Hastuti. 2006. Bimbingan dan Konseling di Institusi Pendidikan. Media Abadi. Yogyakarta.

[3] Peraturan Pemerintah Republik Indonesia Nomor 19 Tahun 2005. (Online), http://www.kemenag.go.id/file/dokumen/PP1905.pdf (diakses 3 Desember 2013).

[4] Prayitno. 2004. Seri Layanan Konseling. Jurusan Bimbingan dan Konseling Universitas Negeri Padang. Padang.

[5] Deni Novia Anggraeni. 2012. Peningkatan Perencanaan Karir Melalui Layanan Bimbingan Kelompok pada Siswa Kelas X-BB SMK Islam Sudirman 1 Ambarawa Tahun Pelajaran 2011/2012. (Online), http://repository.library.uksw.edu/handle/123456789/1804 (diakses 17 Januari 2014)

[6] Audita Christina Silaen. 2008. Hubungan Antara Pemanfaatan Layanan Bimbingan Karir dengan Perencanaan Karir Pada Siswa Kelas XII SMUN-4 Medan. (Online), http://repository.usu.ac.id/bitstream/123456789/23645/6/Cover.pdf (diakses 14 Januari 2014).

[7] Ni Luh Arick Istriyanti dan Nicholas Simarmata. 2014. Hubungan antara Regulasi Diri dan Perencanaan Karir pada Remaja Putri Bali. (Online), http://ojs.unud.ac.id/index.php/psikologi/article/view/8543 (diakses 25 Juni 2014) 